\title{
PENERAPAN MODAL SOSIAL DALAM UPAYA PEMBERDAYAAN MASYARAKAT INDUSTRI BATU BATA
}

\author{
Abdul Sadad dan Mimin Sundari Nasution \\ FISIP Universitas Riau, Kampus Bina Widya Km. 12,5 Simpang Baru Panam, Pekanbaru 28293
}

\begin{abstract}
Application of Social Capital in Empowerment of the Brick Industry
Community. The purpose of this study was to analyze how the application of social capital in an effort to empower the brick industry community in Tenayan Raya District, Pekanbaru City. The development that needs to be done by the government is not just physical development, but development that leads to community development. Social capital which is one aspect of community empowerment is often forgotten. Improving the quality of community life can be done by increasing social capital in the community. Seeing the conditions that occur in the stone stone industry community there has not been a significant economic improvement in improving the standard of living of their families. The method used in this study is a qualitative descriptive method with research instruments in the form of in-depth interviews, observation (observation) and documentation. The results showed that the implementation of social capital in the brick industry community in Tenayan Raya District had not been maximally implemented. From the results of the study it was found that the elements of social capital that most influence the community of Sialang Sakti Village are trust and social networking. Besides that the lack of functioning of community institutions, and the role of community leaders so that it has an impact on community empowerment in order to improve the living standards of the brick industry community in Tenayan Raya District.
\end{abstract}

\begin{abstract}
Abstrak: Penerapan Modal Sosial dalam Upaya Pemberdayaan Masyarakat Industri Batu Bata. Tujuan penelitian ini adalah untuk menganalis bagaimana penerapan modal sosial dalam upaya pemberdayaan masyarakat industri batu bata di Kecamatan Tenayan Raya Kota Pekanbaru. Pembangunan yang perlu dilakukan oleh pemerintah tidak hanya pembangunan fisik saja, melainkan pembangunan yang mengarah pada pembangunan masyarakat. Modal sosial yang merupakan salah satu aspek dalam rangka pemberdayaan masyarakat kerap terlupakan. Peningkatan mutu kehidupan masyarakat dapat dilakukan dengan meningkatkan modal sosial dalam masyarakat tersebut. Melihat kondisi yang terjadi pada masyarakat industri batu batu belum terdapat peningkatan perekonomian secara signifikan dalam meningkatkan taraf hidup keluarga mereka. Metode yang digunakan dalam penelitian ini adalah metode deskriptif kualitatif dengan instrumen penelitian berupa wawancara mendalam, observasi (pengamatan) dan dokumentasi. Hasil penelitian menunjukkan bahwa penerapan modal sosial masyarakat industri batu bata di Kecamatan Tenayan Raya belum maksimal dilaksanakan. Dari hasil penelitian ditemukan bahwa elemen-elemen modal sosial yang paling berpengaruh pada masyarakat Kelurahan Sialang Sakti adalah kepercayaan dan jejaring sosial. Disamping itu kurang berfungsinya kelembagaan masyarakat, dan perananan tokoh masyarakat sehingga berdampak kepada pemberdayaan masyarakat dalam rangka meningkatkan taraf kehidupan masyarakat industri batu bata di Kecamatan Tenayan Raya.
\end{abstract}

Kata Kunci: modal sosial, pemberdayaan, industri batu bata

\section{PENDAHULUAN}

Pembangunan kesejahteraan masyarakat di Indonesia sampai saat ini masih tergolong rendah. Apalagi jika dibandingkan dengan negara-negara tetangga yang jauh lebih maju, kondisi ini menjadikan sebuah tantangan bagi bangsa Indonesia untuk merubah kondisi ekonomi negara ke arah yang lebih baik lagi. Sudah saatnya bagi pemerintah untuk melakukan suatu langkah pemihakan yang nyata bagi kesejahteraan masyarakat. Sedangkan wujudnya adalah berupa pilihan kebijakan dan langkah- langkah strategis untuk memperkuat daya saing perekonomian masyarakat.

Pendekatan yang paling tepat dalam pemberdayaan masyarakat salah satunya dengan pembangunan sektor industri, pemberdayaan masyarakat melalui pendekatan kelompok, dalam bentuk usaha bersama. Prinsip yang dilandasi unsur kebersamaan dan tanggung jawab moral, merupakan landasan peningkatan kesejahteraan masyarakat dalam usaha yang mandiri.

Ada lima keadaan yang memungkinkan industri kecil mampu bertahan dari persaingan 
yang datang dari industri berskala besar adalah sebagai berikut : Pertama, usaha industri kecil bergerak dalam pasar yang terpecah-pecah (fragmented market), sehingga keberadaan skala ekonomi tidak terlalu penting yang menyebabkan skala ekonomi usaha besar tidak menonjol. Kedua, usaha industri kecil menghasilkan produk-produk dengan karakteristik elastisitas pendapatan yang tinggi, sehingga apabila terjadi kenaikan pendapatan masyarakat, permintaan akan produk-produk usaha juga meningkat. Ketiga, usaha kecil memiliki tingkat heterogenitas yang tinggi sehingga dapat menghasilkan variasi produk yang beraneka ragam. Keempat, usaha industri kecil tergabung dalam satu kluster (sentra industri), sehingga mampu memanfaatkan efisiensi kolektif, misalnya dalam hal pembelian bahan baku, pemanfaatan tenaga kerja terampil, dan pemasaran bersama. Kelima, usaha industri kecil diuntungkan oleh kondisi geografis, yang membuat produk-produk industri kecil memperoleh proteksi alami karena pasar yang dilayani terjangkau oleh inovasi produk-produk skala besar. Oleh karena itu perkembangan industri kecil dan industri rumah tangga memegang peranan penting dalam perkembangan ekonomi.

Namun dalam perkembangannya, industri kecil masih belum menjalankan fungsi dan peranannya secara maksimal karena menghadapi berbagai kendala seperti masalah keterbatasan modal, teknik produksi, bahan baku, pemasaran, manajemen dan teknologi. Selain itu hambatan yang dihadapi industri kecil adalah keterbatasan mengakses informasi pasar, keterbatasan jangkauan pasar, keterbatasan jaringan kerja, dan keterbatasan mengakses lokasi usaha yang stategis.

Perkembangan industri kecil termasuk industri rumah tangga yang bersifat informal merupakan bagian dari perkembangan industri dan ekonomi nasional secara keseluruhan. Industri kecil mempunyai peranan yang strategis dalam penyediaan lapangan kerja, menyediakan barang dan jasa yang bermutu dan salah satu yang diharapkan adalah pengembangan industri kecil yang dapat ditempuh dengan cara pemanfaatan sumber daya alam yang tersedia.
Industri batu bata merupakan salah satu industri yang sangat pesat perkembangannya di Indonesia terutama di Provinsi Riau khususnya di Kecamatan Tenayan Raya. Ini disebabkan kebutuhan manusia akan batu bata sangatlah penting terhadap kegiatan masyarakat secara langsung sehingga permintaan akan batu bata akan terus meningkat. Dengan adanya peningkatan permintaan akan batu bata membuat para pengusaha industri batu bata memanfaatkan kesempatan ini untuk dijadikan peluang menarik minat para konsumen untuk membelinya sehingga ini akan berpengaruh terhadap volume penjualan batu bata tersebut.

Kecamatan Tenayan Raya merupakan penghasil industri batu bata terbesar di Pekanbaru, bahkan pemasarannya sampai keluar kota Pekanbaru, seperti kota di Kabupaten Siak, Pelalawan dan Kampar. Industri batu bata ini paling banyak terdapat di Kelurahan Sialang Sakti dan Kelurahan Bencah Lesung. Industri batu bata ini juga banyak menyerap tenaga kerja dan menjadi sumber penghasilan utama bagi rumah tangga di dua kelurahan tersebut.

Modal sosial atau social capital merupakan sumber daya yang dipandang sebagai investasi untuk mendapatkan sumber daya baru. Sumber daya yang digunakan untuk investasi, disebut dengan modal. Modal sosial cukup luas dan kompleks. Modal sosial disini tidak diartikan dengan materi, tetapi merupakan modal sosial yang terdapat pada seseorang. Misalnya pada kelompok institusi keluarga, organisasi, dan semua hal yang dapat mengarah pada kerjasama. Modal sosial lebih menekankan pada potensi kelompok dan polapola hubungan antar individu dalam suatu kelompok dan antar kelompok, dengan ruang perhatian pada kepercayaan, jaringan, norma dan nilai yang lahir dari anggota kelompok dan menjadi norma kelompok.

Dari definisi yang diberikan para ahli tentang modal sosial yang secara garis besar menunjukkan bahwa modal sosial merupakan unsur pelumas yang sangat menentukan bagi terbangunnya kerjasama antar individu atau kelompok atau terbangunnya suatu perilaku kerjasama kolektif. Dalam modal sosial selalu 
tidak terlepas pada tiga elemen pokok yang ada pada modal sosial yang dijadikan sebagai unsur penilaian pada masing-masing jenis modal sosial mencakup (a) Kepercayaan/Trust (kejujuran, kewajaran, sikap egaliter, toleransi, dan kemurahan hati); (b) Jaringan Sosial/Social Networks (partisipasi, resiprositas, solidaritas, kerjasama); (c) Norma/norms (nilai-nilai bersama, norma dan sanksi, aturanaturan). Ketiga elemen modal sosial di atas berikut aspek-aspeknya pada hakikatnya adalah elemen-elemen yang ada atau seharusnya ada dalam kehidupan sebuah kelompok sosial, apakah kelompok itu bernama komunitas, masyarakat, suku bangsa, atau kategori lainnya atau dengan kata lain elemen-elemen modal sosial tersebut merupakan pelumas yang melicinkan berputarnya mesin struktur sosial.

Modal sosial yang merupakan salah satu aspek dalam makna pemberdayaan masyarakat kerap terlupakan. Peningkatan mutu kehidupan masyarakat dapat dilakukan dengan meningkatkan modal sosial dalam masyarakat tersebut. Melihat kondisi yang terjadi pada masyarakat industri batu batu belum terdapat peningkatan perekonomian secara signifikan dalam meningkatkan taraf hidup keluarga mereka.

\section{METODE}

Metode yang digunakan dalam penelitian ini adalah deskriftif kualitatif dengan sumber data dari penelitian kualitatif berupa kata-kata tertulis atau lisan dari orang-orang dan prilaku yang diamati. Tehnik pengumpulan data yaitu observasi, wawancara, dan dokumentasi. Wawancara digunakan sebagai cara utama dalam proses pengumpulan data, kemudian observasi (pengamatan) dilaksanakan secara participant observer, tehnik ini digunakan untuk menggali data dan sumber data berupa peristiwa. Observasi dilakukan secara informal, dengan cara mengikuti, melihat dan mengamati langsung hasil pelaksanaan kegiatan dilapangan. Dokumentasi dilakukan untuk mendapatkan data sekunder dengan cara mencatat dan mengumpulkan berbagai dokumen yang berkaitan dengan objek penelitian. Adapun tehnik analisis data yaitu dengan mengumpulkan, meng- klasifikasikan, dan interpretasi data yang diperoleh dari pengamatan maupun dari dokumendokumen kemudian menarik suatu kesimpulan.

\section{HASIL DAN PEMBAHASAN \\ Penerapan Modal Sosial dan Pemberdayaan}

Definisi modal sosial (social capital) lebih menekankan pada hubungan sosial dan pola-pola organisasi sosial yang diciptakan untuk memperoleh kekuatan yang potensial untuk perkembangan ekonomi. Mereka mengaitkan modal sosial dengan analisis mikro, mezzo, dan makro, sehingga modal sosial tidak bisa dijelaskan dengan istilah investasi (modal) sebagaimana yang dikenal dalam kehidupan sehari-hari. Pada aras makro modal sosial meliputi institusi seperti pemerintah, aturan hukum, kebebasan sipil dan politik. Pada aras mikro, modal sosial berkaitan dengan analisis individu dan keluarga, sedang di aras Mezzo lebih cenderung ke pendekatan komunitas.

Penulis melihat bahwa salah satu aspek penting dalam usaha pemberdayaan yang dilakukan pada masyarakat Kelurahan Sialang Sakti adalah modal sosial. Di dalam hal ini memasukkan kelompok usaha bersama ke dalam modal sosial, sebab kelompok usaha bersama memiliki karakteristik modal sosial. Kelompok usaha bersama berisi serangkaian norma, nilai, dan jaringan yang dapat menggerakkan masyarakat untuk melakukan kegiatan bersamasama untuk tujuan kesejahteraan. Prinsip kekeluargaan, kegotong-royongan, kepercayaan, hubungan timbal balik dan kejujuran yang merupakan dimensi modal sosial yang dikedepankan oleh kelompok usaha bersama ini. Hal tersebut sesuai dengan konsep bahwa modal sosial berkenaan dengan nilai dan norma yang mengatur interaksi diantara individu, keluarga, dan komunitas yang mengejawantahkan dalam berbagai tradisi, kebiasaan dengan rasionalitas masing-masing.

Pengaruh modal sosial terhadap pemberdayaan yang terjadi di masyarakat Kelurahan Sialang Sakti ini sangat besar. Tanpa modal sosial seperti kepercayaan, usaha pengembangan kelompok usaha bersama tidak akan bisa berjalan. Tanpa adanya rasa percaya yang 
terjalin antara anggota kelompok dan pengurus masalah yang terjadi dalam tidak akan terselesaikan.

Elemen-elemen modal sosial yang paling berpengaruh pada masyarakat kelurahan Sialang Sakti adalah kepercayaan dan jejaring. Tingginya kepercayaan akan berpengaruh pada partispasi anggota terhadap kegiatan kelompok usaha bersama, pemberian pinjaman kepada anggota kelompok dan kekompakan kelompok yang secara tidak langsung juga akan berpengaruh terhadap performa kelompok usaha bersama. Jejaring yang dibangun kelompok ini masih kurang, kelompok usaha bersama hanya bisa menjalin jejaring dengan satu pihak luar yaitu Bank dan itu juga hanya sebatas menjadi nasabah. Jika jejaring yang dibangun oleh masyarakat desa terhadap kelompok usaha bersama dapat lebih baik performa kelompok usaha bersama akan lebih baik dan pemberdayaan masyarakat kelurahan melalui pengembangan kelompok usaha bersama akan memperoleh hasil yang lebih baik.

Modal sosial memiliki peran penting dalam perkembangan industri batu bata, karena peran modal sosial pelaku industri sebagai strategi untuk membantu mengatasi permasalahan industri di Kelurahan Sialang Sakti. Dalam perkembanganya norma, kepercayaan, resiprositas dan jaringan saling berkaitan satu sama lainya yang dapat digunakan untuk memecahkan permasalahan industri. Dalam hal ini, peran nilai dan norma sebagai aturan kesepakatan agar industri mereka menjadi lebih terarah, teratur, terorganisir dan mengontrol perilaku yang dapat merugikan industri, serta adanya nilai-nilai sosial seperti nilai kebersamaan, kerja keras, harmonis, kesabaran dan tanggung jawab diantara pelaku industri. Peran kepercayaan dapat mendorong hubungan kerjasama dan memudahkan pelaku industri dalam melakukan transaksi kerjasama. Peran jaringan sosial, jaringan kekerabatan memberi kemudahan dalam mendapatkan informasi dan memperluas hubungan kerjasama. Peran resipropitas menjaga hubungan kerjasama dengan tidak merugikan diantara kedua belah pihak dan saling tukar kebaikan diantara pelaku industri.
Dalam penyediaan modal, peran norma mengontrol perilaku yang dapat merugikan industri dan sistem ijonan dapat menciptakan hubungan kerjasama yang baik. Selain itu, nilai kesabaran, nilai tanggung jawab, dan nilai budaya menjadi pedoman pelaku industri dalam bertindak. Peran kepercayaan penanam modal memberikan kelonggaran waktu pembayaran pinjaman, sedangkan pemilik industri akan membayar kewajibanya dengan tepat waktu. Hal ini dapat memberikan kelancaran proses negosiasi pinjaman modal dan meningkatkan kepedulian penanam modal terhadap pemilik industri. Peran jaringan memudahkan pemilik industri terhubung langsung ke penanam modal karena adanya jaringan kekerabatan diantara pemilik industri. Peran resiprositas penanam modal mendapatkan harga batu bata yang lebih murah, sedangkan pemilik industri mendapatkan pinjaman modal.

Dalam penggunaan bahan baku, peran norma mempengaruhi kualitas batu bata yang dihasilkan, mengontrol perilaku yang dapat melanggar aturan dari pemilik lahan, dan menghindari adanya persaingan dengan menerapkan sistem bagi hasil 17\%. Peran kepercayaan memudahkan pemilik industri mendapatkan bahan baku, karena mereka tidak memberikan jaminan apapun dan pembayaran dilakukan setelah produksi batu bata selesai. Jaringan kekerabatan yang dimiliki pemilik industri memudahkan mereka untuk terhubung langsung dengan pemilik lahan. Resiprositas sebanding dalam penyediaan bahan baku supaya kedua belah pihak tidak merasa dirugikan dan resiprositas umum diantara anggota pemilik industri dapat membantu mengatasi kesulitan pemilik industri.

Dalam perluasan pasar, peran norma dapat menciptakan persaingan sehat dengan adanya ketentuan harga pasar dan nilai kerja keras yang dimiliki pengusaha dapat meningkatkan produktivitas batu bata yang dihasilkan. Peran kepercayaan dengan menghasilkan batu bata yang berkualitas dapat memperkuat kepercayaan konsumen. Selain itu, melancarkan proses negosiasi dengan relasi bisnis saat membantu memasarkan batu bata. Adanya jaringan 
di antara pemilik industri, pemilik lahan, pemilik mobil, dan penanam modal dalam memasarkan batu bata. Peran resiprositas disini yakni saling tukar kebaikan diantara pelaku industri dalam menjual batu bata ke konsumen.

Dalam pemanfaatan tenaga kerja, peran norma menentukan upah buruh dan menciptakan iklim kerja yang positif. Peran kepercayaan mengambil resiko membayar upah diawal kerjasama. Peran jaringan bonding social capital memudahkan pemilik industri dalam menyerap tenaga kerja dan mengatasi permasalahan naiknya upah buruh. Resiprositas disini saling tukar kebaikan diantara anggota pemilik industri dan sesama pemilik industri dalam pemanfaatan tenaga kerja.

Dalam penggunaan teknologi, peran norma mengontrol perilaku pengusaha supaya tidak bertindak curang dan pembagian tugas buruh akan meringankan aktivitas produksi. Peran kepercayaan membuat kelonggaran waktu pembayaran uang sewa. Peran jaringan kekerabatan dapat memudahkan pemilik industri dalam mengakses informasi teknologi yang lebih modern. Resiporitas umum dapat meminimalisir biaya produksi pemilik industri dan resiprositas sebanding supaya pemilik industri tidak merasa dirugikan.

Dalam diversifikasi usaha, peran norma dalam aturan pembayaran jasa sewa mobil dan upah buruh. Peran kepercayaan dapat menambah pendapatan bagi pemilik industri. Peran jaringan dapat memudahkan untuk mendapatkan informasi tentang ekspansi bisnis. Resiprositas dalam pertukaran informasi diantara pemilik industri dengan buruh. Modal sosial memberikan kontribusi penting terhadap eksitensi usaha batu bata. Dalam hal ini, keberadaan modal sosia harus dipertahankan dan diperkuat dengan menjaga ikatan kekerabatan diantara pemilik industri, serta menjaga kepercayaan dengan pemilik lahan dan penanam modal. Menjaga dan melestarikan nilai-nilai budaya lokal yang dimiliki seperti nilai gotong royong, nilai harmonisasi, nilai kejujuran, nilai tanggung jawab, kerja keras, nilai kesabaran dan kebersamaan.

\section{Faktor yang Mempengaruhi Penerapan Modal Sosial}

Elemen modal sosial di pedesaan yang dinilai penting adalah solidaritas, manajemen sosial, jaringan kerja sama dan kegotong-royongan setempat. Peran kepemimpinan sangat penting dalam penguatan modal sosial setempat. Kepemimpinan formal di pedesaan mendapat tempat tersendiri di masyarakat pedesaan. Namun demikian, peran kepemimpinan nonformal umumnya memiliki pengaruh lebih nyata dalam membangun dan memelihara modal sosial. Memperkuat basis kepemimpinan pada tokoh nonformal setempat untuk menguatkan modal sosial setempat dinilai memberikan jaminan lebih baik dibanding jika mengandalkan pada tokoh formal atau tokoh dari desa/ kelurahan. Komponen tata-nilai dasar seperti rajin dan kerja keras, empati, kejujuran atau amanah, sabar, rasa malu atau harga diri, dan hidup hemat adalah kumpulan tata-nilai dasar yang berperan penting membentuk modal sosial di pedesaan.

Kerentanan industri rumah tangga, apabila pemilik industri tidak dapat mengatur keuangan mereka. Dalam hal ini yang perlu dilakukan pemilik industri harus memiliki manajemen dalam berwirausaha, agar dapat mengendalikan perilaku yang dapat merugikan industri mereka. Pemilik industri harus dapat mengatur antara pengeluaran dan pendapatan supaya industri rumah tangga mereka dapat bertahan. Kerentanan usaha lainya seperti tidak lakunya batu bata mereka di pasaran karena kualitas batu bata yang dihasilkan dan jaringan kerjasama yang tidak begitu luas. Dalam hal ini yang perlu dilakukan pemilik industri harus memperhatikan dengan teliti, ulet saat mereka memilih dan mengelola tanah. Pemilik industri harus belajar dengan mereka yang sudah lebih berpengalaman dalam mengelola batu bata.

Selain itu, pemilik industri yang memiliki jaringan kerjasama yang tidak begitu luas harus meningkatkan hubungan sosial mereka di tengah masyarakat dengan menjalin komunikasi dan interaksi yang intens terhadap masyarakat sekitar, supaya ketika batu bata mereka tidak laku, pemilik industri tidak hanya 
bergantung dengan penanam modal. Hal ini didukung dengan memberikan kualitas batu bata yang bagus. Bagi pekerja atau buruh industri rumah tangga supaya tetap menjaga kepercayaan dan tanggung jawab dengan pemilik industri. Selain itu, apabila mereka memiliki keinginan untuk menjadi pemilik industri, mereka harus memiliki sifat kerja keras, ulet, rajin, tekun, tanggung jawab, menjaga kepercayaan terhadap relasi bisnis, dan memperluas jaringan kerjasama, hal inilah yang biasanya diasosiasikan sebagai modal sosial.

\section{SIMPULAN}

Dengan pengembangan kelompok usaha bersama akan terjadi penguatan modal sosial dalam upaya pemberdayaan masyarakat kelurahan. Akan tetapi, masih ada aspek-aspek yang kurang seperti jejaring yang masih sempit. Walaupun demikian, penguatan modal dalam upaya pemberdayaan masyarakat kelurahan ini dapat membuat masyarakat lebih berdaya dengan kelompok usaha bersama sebagai modal sosial mereka. Elemen-elemen modal sosial yang paling berpengaruh pada masyarakat adalah kepercayaan dan jejaring. Jejaring yang ada pada kelompok usaha bersama harus diperluas lagi karena hal tersebut akan memperkuat aspekaspek modal sosial yang ada. Pengembangan model penguatan modal sosial memerlukan latar belakang pemahaman yang mendalam tentang penguatan tata nilai, keorganisasian masyarakat berbasis komunitas kecil, manajemen sosial yang sehat, kepemimpinan nonformal, dan penyelenggaraan pemerintahan yang baik. Oleh sebab itu, pemberdayaan mas- yarakat kelurahan melalui penguatan modal sosialnya perlu diletakkan dalam bingkai transformasi atau pembangunan masyarakat pedesaan secara berkelanjutan.

\section{DAFTAR RUJUKAN}

Bourdieu, P. (1983). 'Forms of capital' in J. C. Richards (ed.). Handbook of Theory and Research for the Sociology of Education, New York: Greenwood Press. Dikutip dari situs www.google. com - social capital: civic community and education/social_capital

Fukuyama, Francis. 2002. Trust: Kebajikan Sosial dan Penciptaan Kemakmuran. Yogyakarta: Qalam

Hasbullah, Jaousairi. 2006. Social Capital: Menuju Keunggulan Budaya Manusia Indonesia. Jakarta: MR-United Press

Hikmat, Harry. 2001. Strategi Pemberdayaan Masyarakat. Bandung: Humaniora Utama

Sumodiningrat, Gunawan. 1998. Membangun Perekonomian Rakyat. Yogyakarta: Pustaka Pelajar

Suharto, Edi. 2014. Membangun Masyarakat Memberdayakan Masyarakat. Bandung: Refika Aditama

Zubaedi. 2013. Pengembangan Masyarakat Wacana dan Praktek. Jakarta: Kencana Prenada Media Group

Joesron, M Fathorrozi. 2003. Teori Ekonomi Mikro, Jakarta: Salemba Empat

Mahmud, Syamsuddin. 2005. Dasar-dasar Umum Ekonomi dan Koperasi. Jakarta: Internusa. 